University of Louisville

ThinkIR: The University of Louisville's Institutional Repository

Electronic Theses and Dissertations

$5-1921$

\title{
The relation between man and nature in Wordsworth's poetry.
}

Elizabeth Hoskins

University of Louisville

Follow this and additional works at: https://ir.library.louisville.edu/etd

\section{Recommended Citation}

Hoskins, Elizabeth, "The relation between man and nature in Wordsworth's poetry." (1921). Electronic Theses and Dissertations. Paper 638.

https://doi.org/10.18297/etd/638

This Master's Thesis is brought to you for free and open access by ThinkIR: The University of Louisville's Institutional Repository. It has been accepted for inclusion in Electronic Theses and Dissertations by an authorized administrator of ThinkIR: The University of Louisville's Institutional Repository. This title appears here courtesy of the author, who has retained all other copyrights. For more information, please contact thinkir@louisville.edu. 
UN IVERS ITY OF LOUISVILLE

THE RELATION BETWEEN MAN AND NATURE

IN WORDSWORTH'S POETRY.

\section{A Dissertation}

Submitted to the Faculty

of the Graduate School of Arts and Sclences

In Partial Fulfillment of the

Requirements for the Degree

of Master of Arts

Department of English

By

Elizaboth Hoskins

1921 


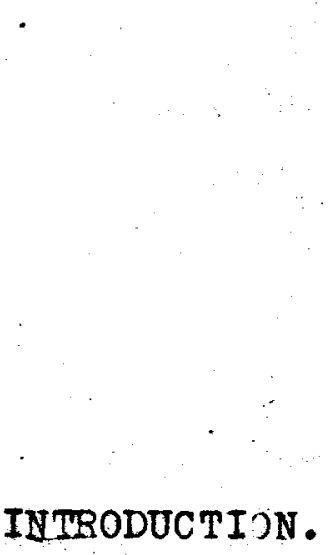

1

INTRODUCTION.

\section{.5109}




\section{Introduction.}

Wn1le democracy was developing, while men were seeking to reform national politics and to find some means by which the people might be represented justly in the government, a new movement entered into 11terature to give it a broadened scope and a deepened meaning. Th1s was the philes osoph1cal movement, - at times strongly influenced by a metaphysical spirit, which often "not only prescribed the form of poetry, but furnished 1t with 1ts elements". (Taline, History of Engl1sh Literature, p. 87). The questions, What is the meaning of life? What is man, and what is his purpose in the world? turned the thoughts of men Inward upon their own souls to find, if possible, the anmers. The question, how to live, was recognized as moral one; "1t is the question which most interests every man, and with whlch, in some way or other, he is perpetually occupled". (Arnold, Essays In Crit1c1sm, p.147) As a result, the habits of introspection and of profound mealtation characterized the poets of this period, and it rematined for Wordsworth, as the chlef representative of this new movement, to establish a name and place for himself unlike that of any other English poet.

In this paper, then, it is my purpose to examine Wordsworth's position as a philosophic poet and to show that this position does not rest upon the dry dust of a "scientific 
system of thought". By tracing the development of his love for Nature through his chlldhood, his youth, and his matumty, I wish to present Wordsworth's wholly new and individual view of Nature, which forms the basis for his unique position. Further, I desire to show how, through the Influence of Nature, he was brought to that love and sympathy for mankind, that broad comprehension of the workings of man's mind, which make him, In the truest sense, a phllosophical poet for those who approach him with "a seeling eye and an understanding heart". 
CHAPTER $\boldsymbol{I}$.

WORDSWORTH'S POSITION AS A POET. 
Wordsworth's Position as a Poet.

Before we consider the position which Wordsworth maintains as a poet, let us see, first, in what light Fordsworth regards a poet and poet's responsibilitles. Although endowed with greater sensibilitses, a greater understanding, and "a more comprehensive soul" (Lyrlcal Ballads, p. 237) than the average person, what is a poet, after all, but a man whose realm is mankind,-"a man speaking to men" (Lyrical Ballads, p. 237). Further, "to these qualities the Poet has added a disposition to be affected more than other men by absent things" and "from practice he has acquired a greater readiness and power in expressing what he thinks and feols, especialiy those thoughts and feelings which, by hts own choice, or from the structure of his own mind, arise in him. Without immediate external'excitement". (Lyrical Ballads, pr 237). The poet's wish is "to bring his feelings near to those of the persons whose feelings he describes, nay, for short spaces of time port haps, to let himself step into an entire delusion, and even confound and ldentify his ann reelings with theirs (p. 239). It was his own purpose as a poet, Fordsworth tells us, nto follow the fluxes and refluxes of the mind wen agftated by the great and simple affections of our nature" (p. 229) in language "near to the language of men", (p. 232), and "to 1llustrate the manner in which our feelings and ldeas are associated in a state of exc1tement" (p. 229). 
He does not choose his characters from anong the demi-gods and heroes of history and romance; nedther does he sing of court If and court figures, with all the ceremonial, artificlal environment surrounding them. Instead, he presents to us as his heroes, Itving chlldren, women; and men from humble rastic Iffe. In the life of the peasant, Wordsworth feels that the true dignity of manhood is more apparent, and that its derelopment 18 more certain than it is in the life of the courtier, because there "the essentlal passions of the heart find a better soll in which they can attain their maturity, are less under restreint, and speak a plainer and more emphatic language". (Lgrical Ballads, p. 226). He loves and understands the sturdy peasant folk; he makes no attempt to anatomize the structure of the human mind or heart, but by watching closely the simple people among whom he walked daily-both old and young,-- he does observe with remarkable sympathy and knowledge their ways, thoughts, and emotions. With intense interest he notes the diverse manifestations of these thoughts and "passions of the heart", and records his observations so that we can understand. But wordsworth has a deeper purpose in writing than merely to portray the trials, the joys, the thoughts, and the feelings that are common to us all. Wordsworth definitely announces the task that he has undertaken and the theme of his work. 
"On Man, on Hature, and on Human Life, Musing in solitude I oft percelve Fair trains of imagery before me rise, Accompanied by feelings of delight

Pure, or with no unpleasing sadhess mixed, And I am conscious of affecting thoughts And dear remembrances, whose presence soothes or elevates the Mind, inteht to weigh The good and evil of our mortal state. - To these emotions, whencesoe'er they come, Whether from breath of outward circumstance, or from the Soul-- an impulse to herself-I would glve utterance in numerous verse. * * a ln mu

of the individual Mind that keeps her orn Inviolate retirement, subject there

To Consclence on $1 \mathrm{y}$, and the law supreme of that Intelligence which governs all-I sing-- 'fit audience let me find, though fer! "

(Regluse)

He does more, however, than simply announce his theme. He insists again and again that "the discerning intellect of Man, when wedded to this goodly unfverse in love and holy passion" (Recluse, Iines 52-54) is "my haunt, and the main region of my song" (11ne 41). After searching the mysterious depths of his own impulses and experiences, Fopdsworth is 4 convinced that men has within himself all the elements necesarry to perfect his iffe, if only he will follow Nature steadfastiy as his guide, so that she may show him how to learn the great lesson of living. His "high argument" (line 71) is to show "How exquisitely the individual mind * * To external Worlds Is fitted:- and how exquisitely, too-Theme this but little heard of among men-The external World is fitted to the Mind."

(Recluse, Iines 63-66) 
Here is a subject, then, to inspire a true poet to the noblest poetry! Therefore, we must belleve that

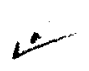
Wordsworth is not interested in Nature primarily for Nature's sake. He is not a simple, naive poet who, because he is an enthusiastic naturalist, writes about the buds, the fiowers, the beauty, and the wonder of Nature. The love of natural things 1s, in Wordsworth, a different feeling from the attraetion which other poets, previous to him and in his own day, felt toward Nature. His profound and original conviction is that between man and nature exists a harmonious consciousness, a mystic inter-dependence and strength. Nature reveals to him, in ways without number, fascinating and mpsterlous openinge into the apparently impenetrable depths of things. Although he rejoices in the sprightly, dancing daffodils, in the rich gold of their color, the wealth that this happy host of flowers brings to him is not purely the trasitory feeling of pleasure at the pretty sight; his cause for rejolcing lies in this fact:

$$
\begin{aligned}
& \text { "Oft, when on my couch I lie } \\
& \text { In vacant or in pensive mood, } \\
& \text { They flash upon that inward eye } \\
& \text { Which is the bliss of solitudo." }
\end{aligned}
$$

(I Fandered Lonely As a Cloud b most unattractive blossom, and

$$
\begin{gathered}
\text { "One impulse from a vernal rood } \\
\text { May teach you more of man, } \\
\text { Of moral evil and of good, } \\
\text { Than all the sages oan." } \\
\text { (The Tables Turned) }
\end{gathered}
$$


Thus, it was Wordsworth's special mission to interpret rather than to describe, and he dedicated his life to show

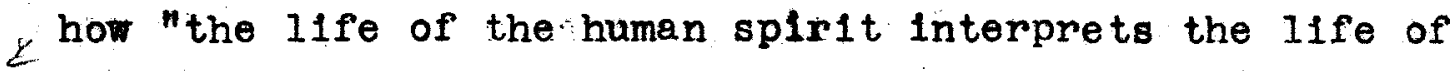
Na ture". (Dowden, Introduction to Wordsworth's Poems). We cannot doubt that wordsworth was keenly aware of a deep sense of consecration to his task. He has a trust to fulfill, a message to proclaim, which he feels is of divine Inspiration. The poet, even as the prophet, possesses a fift of Heaven, a "sense that fits him to percelve objects unseen before". (Prelude, XIV, 303). As a prophet of Nature, then, and as a teacher, above all else, Wordsworth would speak
"A lasting inspiration, sanctified By reason, blest by falth: what we have loved, others will love, and we will teach them how; Instruct them how the mind of man becomes A thousand times more beautiful than the earth On which he dwell."
(Prelude, XIV, 445)

"That Wordsworth did was to deal with themes that had been partialiy handled by precursors and contemporaries. in a larger and more devoted spirit, with wider amplitude of illustration, and with the steadfastness and persistency of a religious teacher". (Morley, Introduction to Wordsworth's Poems) He, himself, had no teachers save Nature and the power of tranquil contemplation; which enabled him to make "his powerful and beautiful application of Ideas to life". (Arnold, Esags In Crit1c1sm, "Wordsworth", p. 138).

Therefore, if we accept Wordsworth's self-expressed desire to be considered as teacher or as notheng, we must 
belleve that he has a phllosophy, - a very noble one, - which urges him on and fustifles his desire. Mr Arnold rebukes the Wordsworthlans for pralsing Wordsworth's system of phflosophy and his scientific system of thought. He tells us that"his poetry is the reality, his philosophy,- so far, at least as it may put on the form and hablt of a 'scientific system of thought', and the more that it puts them on,- is the 11lusion." (Arnold, Essays in Critic1sm; "Wordsworth", p. 148). If, by this statement, Arnold means that Wordsworbh determined to clothe in verse an ordered system of philosophy and sclentiflc thought which he would thrust upon us, then I agree, with Arnold that the less emphasis placed upon such a mechanical procedure, the better. Such a system would be only for the few, not for man as a whole! To.me, however, Tordsworth's philosophy goes deeper than a formal, scientifically arranged system. It is impossible for me to belleve that, in the brooding meditation which eharacterized his life, in his profound reflections on man and nature, he could escape being a ph110sophic poet; nor do I think that he could have written on life as he did without that philosophy. Arnold asserts that Wordswerth's superiorsty to other poets lies in the fact that "he deals with more of I1fe than they do; he deals with iffe, as a whole, more powerfully". This fact, I think, entitles him to be called a philosophic poet. He has earned it by his plain living and lofty thinking,- not by his system of philosophy, In writing his best poetry of life, "Neture 


\section{0.}

herself seems * * to take the pen out of his hand, and to write for him with her own bare, sheer, penetrating power." Arnold, Essays in Criticism, "Wordsworth", p. 158). Since it is Nature's undisputed role to comfort, to heal, to strengthen, $V^{\prime}$ and to gulde, Nature and philosophy are inseparably bound together; therefore, Wordsworth's poetry must be philosoph1cal. In his own Iffe his philosophy enabled him to be true, above everythirg else, to himself and his convictions, and it taught him the great lesson of "living, not for things temporal, but Vifor things eternal".

"We will grieve not, rather find Strength in what rema ins behind; In the primal sympathy Which having been must ever be; In the soothing thoughts that spring Out of human suffering; In falth that looks through death In years that bring the philospphic mind". (ode. Intimations of Immortality.) 


\section{CHAPTER II. \\ WORDSWORTH'S FEELING TOWARD NATURE IN HIS CHILDHOOD AND YOUTH.}


Wordsworth's Feeling toward Nature

In His chlldhood and Youth.

From my tudy of Wordsworth, I feel that upon his new and Individual conception of Nature rests the basis of the phllosophy which characterized hls poetry. I have already sald that Wordsworth is not a poet of Nature for Nature's own sake. His genius "lay in detecting "ature's influences just at the point where they were stealing unobserved into/the very essence of the human soul", (Hutton, Fordsworth and his Genius, p. 218), and in interpreting the living expressions of those influences. Wordsworth, more than any other poet, stresses the moral Influences that Nature brings to bear upon man's life and spirlt; and in his recognition of her divine unfluence as we 11 , he peredives that "1t is in the power of Nature to penetrate his splrit, to reveal him to himself, to communicate to him divine instmuctions, to lift him into spiritual Ifro and ecBtasy." (Daws on, Literary Leaders of Modern England, p. 22). To Wordsworth, Nature is a living, inspiring personality, animated by a soul which can ennoble man's nature and elevate his soul by 1 ts contact. Confident that "Nature never did betray the heart that loved her", (LInes), he is content in her ministry. She is

\footnotetext{
"The anchor of my purest thoughts, the nurse, The gulde, the guardian of my heart and sovl, of all my moral beling."

(LInes)
} 
This original view of Nature was not a theory that Nordsworth happened upon by accident in his maturity. It seemg to me that such a view had to be; it appears, in Wordsworth's case, to have grown up with hIm as he grew. From his own account of his childhood, his youth, and his maturity, we can discover his feelings and his attltude in each of these periods toward Nature; we can see that each of these three stages bas Its own unity; that all are different, all are separate, and all are causally related. Truly "the child is father of the ran" in the case of Wordsworth! From his earliest chllahood, Nature exerted a strond unconsclous influence over. Him. He writes-

" * * Even then

I held unconsclous intercourse with beauty

old as creation, drinking in a pure

Organic pleasure from the silver wreaths

of curling mist, or from the level plain

of waters colored by impending clouds."

(Prelude, 562)

He absorbed "ature whout any consctous effort of 1111 , and this period was characterized by impressions -- senattione, Wordsworth calls them -- and lack of thought. It ras ating of simply being, combined ith total ignorance of Hature, which fact permitted his chlld-nature to be the more readily influenced. In recelving these sensations, the child is passive, but it is a passivity that is not helplessness. On: the other habd, It is not the "wise passiveness" of later years, but has in its meaning an implied activity which results in the "glad animal movements" and "dizzy raptures" 
thet Wordsworth tells us he experlenced in his childhood. In the Ode on Intimations of Immortal1ty, Wordsworth asserts that the simple creed of chlldhood consists of liberty and delight, and certainly these formed the creod of his own early adolescent years. Again and again he remarks on the perfect freedom of the perlod of his life, and the pure, animal enfoyment that was his through his companionship with the glad, external things of Nature. Te know that when. he was five years old, he rejolced in Nature like a little savage, running wild among the hills and woods, or making "one long bathing of a summer's day". (Prelude, I, 289). As a child he says he learned to love the sun because of the sheer beauty of sunrise and sunset on the hills and the "aching joys" it caused him; for its purely physical charm, the moon was aloo dear to him, and the blue gleaming river that flowed past his home was a tempting, much-loved playmate. He was free to scour the flelds of sand about hls bome, or to leap "through fiowery groves of yellow ragwort" in thoughtless happlness. His blood seemed to flow for its own pleasure, and he tells us that he "breathed with joy".

The love of "ature was, in this period of Wordsworth's IIfe, a healthy appetite; at this time every changing phase of Nature held a new interest and wonder for him.

"While yet a child, with a child's eagemess Incessantly to turn his ear and eye On all things which the moving seas ons brought To feed such appetite." (Excursion, I, 149) 
Again in Tintern Abbey he repeats this thought.

"The mountain and the deep and gloomy wood,
Their colors and their forms, were then to me
An appetite."

The love that Hordsworth felt for Nature as a child had "no need of a remoter charm by. thought supplied, not any interest unborrowed from the eye". (IIntern Abbey). That we speak of in phllosophy as the "eye sense" was then the predominating faculty; thus Nare reached him entirely through sensations or sense-impressions which, growing in power as he approached the period of his youth, gradually awakened "gentlo agitations of the mind", and aroused his mental activity.

"Oft amid those fits of vulgar joy

Which, through all seasons, on a child's pursults Are prompt attendants, 'mld that giddy bliss Which, like a tempest, works along the blood And is forgotten; even then 1 felt Gleams like tha flashing of a shleld;- the earth And common face of Nature spake to me Rememberable things." (Prelude, I, 581)

Wordsworth, in The Prelude, marks the tenth jear of his iffe as the beginning of his boyhood on youth, as distinct from his chlldhood. From this time, the range of his boylsh sports increased; the forbldaing, dizzy crags of the mountains which surrounded the Lake Region dared him to perilous ascents with a temptation as welcome to him as it was insisteht. The $\downarrow$ sounding cataract at this time haunted him "like a passion". Thus among his mative hilis and valleys he led a vigorous life of sport and activity such as any normal, healthy boy enfoyed; 


\section{6.}

but now he began to be consclous of a certaln sense of awe, a feeling of something like mystery which Nature inspired in him. There does not seem to have been anything unnatural or morbid in thas feeling; it only reminds us how keenly sensitive Wordsworth was to Nature, and how his boylsh consclousness responded, although at the time in an unexplainable way, to the spirit "that lature breathes among: the hills and groves". (Prelude, I, 281).

He experienced the foys of nutting, riding, skating, and swimming. All the sports dear to boyhood he shared in common with every wholesome youth, deriving from them more enjoyment, possibly than the average boy,- but, these "coarser pleasures" lso served to develop that feeling of awe, and to touch him with a reverence for Nature surely and for all time.. The poem Nutting, besides describing vividiy that enjoyable sport, gives us an Instance of how susceptible he was to the influence of Nature." "In eagerness of boyish hope," "ordsworth tẹlls us, "I left our cottage-threshold, sallying forth." (Nutting). A boy does not go forth in presentable gaments to gather nuts; nelther did this one:

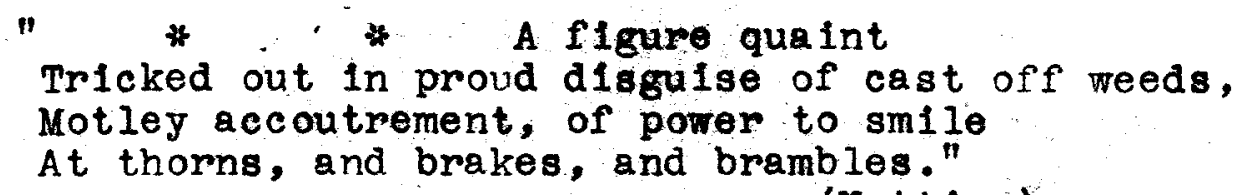

Quite characteristic of boyhood it is too, that he did not immediately begin to pick the hazel nuts when he found the 


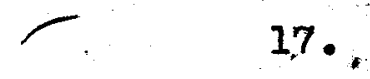

place where they grew; but, tempted by the sparkling water, he rested for a bit with his cheek on one of the cool, mossy C'stones. Then he plunged enthusiastically into his nut gathering.

"Dragged to earth both branch and boughs, with crack And merciless ravage; and the shady nook of hazels, and the green and mossy bower Deformed and sullied, patiently gave up Their quiet being."

(Nutting)

But in the midst of his exultation over the quiet wealth of nuts he has gathered, he feels a sense of pain at having plundered a sacred spot; for in the solitude, among those silent trees, he is conscious that "there is a spirit in the Woods"! (Nutting)

In the Prelude, we find stiking examples of Nature's curious ablilty to make her presence known to the boy Wordsworth on the most unexpected occasions. While still retaining the "great birthright of our being", childhood's sensibility to external Nature, Wordsworth became conscious gradually of a "plastic power", a "forming hand" within himself, which transferred to the objects of Nature his own feelings, making them subjective and internal, instead of objective and external. Take, for example, his description of how he spent one of hte starlit nights on the hills, gleefully setting traps for woodcocks. Hastening expectantly from snare to snare, he came across birds entrapped by another's efforts, and the temptation to steal them was irresistible. But afterwards, when he had 
captured the prey that was not rightfully his, he had heard 10w breathings coming to him and "sounds of undistinguishable motion, steps almost as silent as the turf they trod." (Prelude, I, 325).

Again, while hanging high on a slippery crag above a raven's nest which he had se 7 out to rob, he was impressed not by the fear of falling from his perilous position but by the curlous sound of the wind in his ears.

"W1th what strange utterance did the loud dry wind Blow through my ear! The sky seemed not a sky of earth - and with what motion moved the clouds!" (Prelude, I, 338)

As a boy, Wordsworth seems to have responded to anything which in 1 ts accomplishment required an element of disobedience: Forbidden pleasures which he must obtain by stealth attracted him as they do the average boy today, and he relates vividly his experience while rowing on the lake one summer evening. We appreciate his "troubled pleasure" as he furtively unloosened a little boat that he found in a rocky cave tied to a willow tree; we can hear the "volce" of the mountain-echoes" as he tried unsuccessfully to push the boat off shore without a sound. Then. Wordsworth give us an unusually beautiful picture, a thing he does not always accomplish when he is interested chlefly in recording an experience and not a pure description, He says:

" * * My boat moved on; Leaving behind her sti11, on elther side, Small circles glittering idly in the moon, Unt1l they melted a 11 into one track of sparkling light." 


\section{) 19.}

Fixing his gaze on a craggy ridge, "the horizon's utmost boundary", he set out to row toward that ridge as a goal, rejolcing in his lusty strength and skill. Suddenly, from "bebind that craggy steep" a strange apparition appeared.

" * A huge peak, black and huge, As if with voluntary power instinct, Upreared 1ts head. I struck and struck again, And growing still in stature, the grim shape Towered up between me and the stars, and st1l1, For so 1t seemed, with purpose of 1ts own And measured motion like a living thing Strode after me." (Prelude, I, 378)

Frightened, trembling, Wordsworth tumed and rowed back over the silent water to the place where he had found the bogt. Then he went home, grave and pondering, and for many days he was a mare "of a dim and undetermined sense of unknown modes of being". (Prelude, I, 392).

On st1ll another occasion, Nature intervened with one of her phenomena to make hlm feel her mystic power. One cold, clear evening, Wordsworth and-some of his boy companions, rejolcing in the keen, frosty atr, strapped on their skates, and on "the polished Ice", skimmed like spirited horses through the crisp twillght. The precipices and the distant hills sent their echoes to mingle with the din of happy volces and the clatter of steel. Then Wordsworth, as he often did, when with a crowd, left his companions, and alone on a silent bay at tempted

"To cut across the reflex of a star That fled, and, flylng still before me, gleamed Upon the glassy plain." (Prelude, I, 450) 


\section{0.}

With the swift motion of skating, the shadowy banks of the bay whirled spinning by as he swept along; but suddenly he stopped short, and then a strange thing, happened. The cliffs continued wheeling past him, as if the earth were moving around with a visible motion: Wondering, he watched until gradually the movement ceased and "all was tranquil as a dreamless sleep". (Prelude; I, 463). By these means Naturo made her presence known to Vordsworth, and

" * * through many a year

Haunting me thus among my boyish sports

On caves and trees, upon the roods and hills

Impressed, upon all forms, the characters of

Danger or desire." (Prelude, I, 468)

Thus, in his youth, disciplined by fear as well as love of Nature, Wordsworth could say:

"Fair seed-time had my soul, and I grew up Fostered al1ke by beauty and by fear."

(Prelude, I, 301)

He had felt the power of Nature within him and was now prepared

"By his intense conceptions to receive Deeply the lesson deep of love which he, Whom Nature, by whatever means, had taught To feel intensely, cannot but recelve.

(Excursion, I, 193)

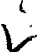

We find, then, that by degrees the joyous,

unthinking animal activities of his childhood days lost the ir charm for him; in this period of youth, as his mind was beginning to develop and the power of thought was awakened, Nature dominated his $11 f e--$ she became all in all to him. Before his eighteenth year, he tells us that "he was o'erpowered by 
Nature". (Excurstion, I, 282).

"Thus while the days flew by, and the years passed on,

From Nature and her overflowing soul

I had recelved so much, that all my thoughts

Were steeped in feeling."

(Prelude, II, 396)

Since Wordsworth had not yet come into maturity, the age of Reason, Imegination, which is the kepnote of the unifying principle of his life and work in his manhood, still slept, Fancy, "Nature's secondary power", by which term Wordsworth means the mixing of the objective with the subjective, colored the world about him in his youth with the glamour and misleading hues of his own feelings.

"To every natural form, rock, fruit, or flower, Even the loose stones that cover the h? ghway, I gave a moral life: I saw them feel, or linked them to some feeling: the great mass Lay bedded in a quickening soul, and all That I beheld respired with inward meaning." (Prelude, III, 127)

Hé says:

"I had a world about me-- ltwas my own;

I made it, for 1t only lived in me."

(Prelude, III, 14I)

This world which he bullt around himself under the enthralling sovereignty of Nature was an inevitable and a vital one at this particular stage of his iffe; through it he was able to mount "to community with highest truth" when in maturity, under the domination of thought, the "open eye of Reason" converted it into a real and ordered universe. 
CHAPTER III.

NATURE IN WORDSWORTH'S MANHOOD:

UN ITY BETWEEN NATURE AND MAN. 
Nature in Wordsworth's Manhood:

Unity between Nature and Man.

In the early years of Wordsworth's manhood, the revolutionary movenent was developing in France, and now Wordsworth transferred tha passionate and absorbing interest with which he had regarded Nature to the political affalrs of France. With the blood of the cumberland dalesmen in his veins, he was, literally speaking, a born democrat; for the dalesmen In this region maintained.a sturdy independence and a perfect equality in all their relations with each other that fostered such a spirit. From the very first, Wordsworth was intensely affected by the Revolution; and now with all the ardor and zest of his liberty-loving nature he flung himself into the cause. To political problems he had always been indifferent. Now, their solution became a real and engrossing experience for him. With a falth that was too sanguine and optomistic, he foresaw only a glorious, triumphant outcome for the Revolution, and the sweeping away of the ev1l and horror of the ola regime. The belief in human perfectibllity possessed him; hopes for a world-wide regeneration of ldeas and institutions filled his heart, and he egerly awaited the day that

"Should see the people having a strong hand In framing their own laws; whence better days To all mankind." (Pre Iude IX, 530) 
Cheered by the outlook of affairs after his first visit to France, Wordsworth returned to Paris where the subsequent developments utterly demolished his hopes and filled his soul with grief and despalr. His spirit sickened at the madness and the carnage of the Reign of Terror. That Englandy his country, should take up arms against the rrench Republic confounded and shamed him; and he was overcome

" $*$ by dark
Imaginations, sense of woes to come,
Sorrow for human kind, and pain of heart."

(Pre lude $X, 328$ )

But the greatest shock that he suffered was the realization that this war for liberty and ideals, which so nearly cost him his love for his native land, was turned by those very advocates of freedom into a war for the conquest of weaker peoples.

"But now, become oppressors in their turn, Frenchmen had changed a war of self-defense For one of conquest, losing sight of a 11 Mhich they had struggled for." (Prelude XI, 206)

At first stubborniy resentful, attempting to hide "the wounds of mortifled presumption", he felt the absolute need of something to save his faith in the goodness of human nature and his trust in the whole framework of social and political iffe. And so in desperation, to restore his hopes and belief, he turned to Rationalism and abstract ressonings of political philosophy. 
"I summoned my best skill, and tolled, intent To anatomize the frame of social life; Yea, the whole body of society Searched to its heart." (Prelude, XI, 279)

But what mental chaos resulted from his efforts to drag "all precepts, judgments, maxims, creeds, like culprits to the bar"! (Prelude, XI, ). Convinced one moment, disbelleving the next, Tordsworth was wearied out and perplexed; and "the heart that had been turned aside from Nature's way by outward accidents" was forced to aband on moral questions in despair. At this period came the great turning point in Wordsworth's 11fe. At "his soul's last and lowest ebb", his sister Dorothy, who understood his nature better than he understood himself, brought him by her wise and gentle influence to the conviction that he had a mission to fulfill, a message to communficate to mankind. She realized, when he did not, that he was unfitted by Nature for participation in public affalrs, and with untiring devotion she revealed to him his own peculikr power and encouraged him to develop it. Wordsworth tells us that she maintained for him a saving intercourse with his true self.

"She in midst of a 11, percelved me still A Poet, made me seek beneath that name, And that alone, mo office upon earth."

(Prelude, XI, 346)

She hedped him to renew that former communion with Nature, whom he had thrust aside for other interestg; and in Nature he found healing and comfort. Surrounded aga in by the 
mountains which he had loved as a youth and by the simple beauty and peace of the country, he regained strangth of spirit and $\mathrm{mind}$ as

" * * Nature's self,

By all varleties of human love

Assisted, led me back through opening day

To those sweet counsels between head and heart

Whence grew that genuine knowledge fraught with peace." (Prelude, XI, 350)

Communion with Nature was now fraught with a different meaning for Wordsworth the man. Having made the acquaintance of evi1, pain, and sorrow during the years of the Frence Revolution, he returned to Nature with his vision deepened and broadened, and his sensibilities more keen than before. Byron, his tempestuous, warring spirit in revolt against soclety, also turned from his fellow man.to Nature, and in her wilder and more turbulent aspects found an outlet for his own stormy emotions. But such an attitude toward Nature served only to allenate Byron more completely from the interests and affalrs of other men. On the other hand, although Wordsworth's pride had been deeply hiurt, and although the falseness of men to their principles had caused him to suffer polgnantly and had strained his faith in both principles and men to the point of breaking, st1ll the consolation which Nature offered served to bring him into a closer and more understanding relation with his fellow men than before.

"For I have learned

To look on Nature, not as in the hour of thoughtless youth; but hearing of tentimes

The still, sad music of humanity." (Lines) 
"Wordsworth lived with Nature, yet waged no angry, railing war against society." (Morley, Introduction, p. 11).

Patiently and surely, Nature wrought in him "tranquil restoration" of the loved objects and sensations of his childhood and youth; but no longer, as in his youth, did his own moods and feelings color the famlliar aspects of Nature. "He does not take his mood to Nature and persuade himself that she reflects 1t; but he goef to vature with an open mind, and leaves her to create the moad in him. He does not ask her to echo him; but he stands docile in her presence and asks to be taught of her." (Dawson, Literary Leaders in Modern England, p. 22). That world which in his youth he had built about him was now inadequate. Like some great building, constructed out of the most enriching, most enduring materials according to a plan that, architecturally, was ornate, perhaps, but inferior and unsound, Wordsworth had fashioned his youthful world out of substantial stuff. The"glad animal movements" and the joyousness of his childhood, the feelings and sensations of his boyhood, resulting from his close and constant touch with $N_{\text {ature, }}$ were in 1 ts making, and they were imperishable. But the design was faulty. Fancy, which made up the flimsy framework of the stmucture, weakened and gave way. In his maturity, with an altogether new plan drawn up by Reason, he set about reconstructing, out of the same indispensable materials, a real and harmonius world which had as its foundation the unity existing between Nature and Man. 
As he adjusted himself to this new world and to new phases of thought and interests, he realized that to $h$ is manhood Nature had intrusted the consummation of her plans for him. In subduing him, he says, she

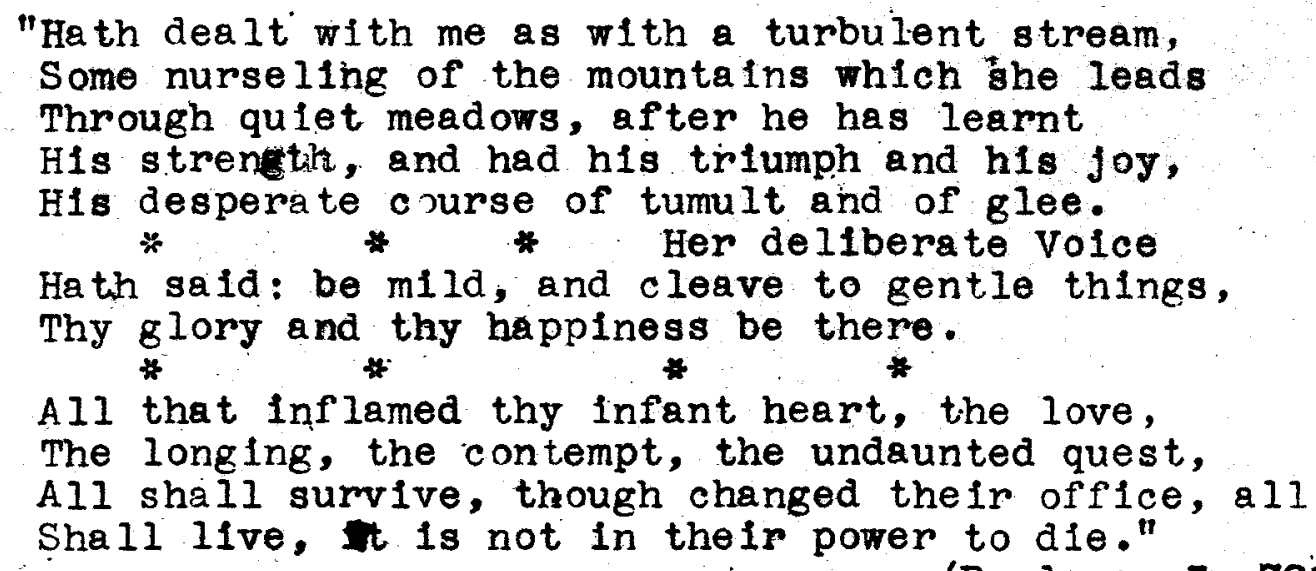
(Recluse, I, 726)

Now we recogitize that the eager impulses, the passions of his youthful days, and the distressing anxieties of his early manhood were neither wasted nor without ava11. We find that they remalned, transmuted and exalted, to perfect his iffe and work by their influence. And so, instead of a world harassed by ceaseless strivings of his intellect which sought in vain to make it conform to a system, Wordsworth discovered a world of peace. The mere wonder of living enthralled him, and he was now content to accept ture's teachings as he contemplated her in "wise passiveness".

"Sweet is the lore which Nature brings; our meddling intellect

Mis-shapes the beauteous forms of things:We murder to dissect.

Enough of Sclence and of Art; Close up those barren leaves; Come forth, and bring with you a heart That watches and recelves." (The Tables Turned) 
Wordsworth's heart, watching silently and reverently before Nature's majestic presence, recelved in infinite measure rich gifts from her "world of ready wealth". In this perlod of maturity, his vigliant, attentive attitude of heart was accompanfed by a resulting involuntary alertness of his sense perceptions; and together they constututed the means by which Nature instructed him.

"The eye - 1t cannot choose but see;

Te cannot bid the ear bo stili;

our bodies feel, wherer they be,

Against: or with our wili.

Nor less I deem that there are Powers

Which of themselves our minds impress; That we can feed this mind of ours In a wise passiveness.

Think you, 'mid all this mighty sum of things forever speaking, That nothing of itself will come, But we must otill be seeking?"

(Expostulation and Reply)

Her "school subline" was

"Not 'mld the World's vain objeots that enslave The free-born Soul - that World whose vaunted skill In selfish interest perverts the will, Whose factions lead astray the wise and brave,Not there; but in dark wood and rocky cave, And hollow vale which foaming torrents fill With omnipresent murmur as they rave, Down their steep beds, that never shall be still: Here, mighty "Nature!"

(Composed While the Author was Engaged in Nriting

a Tract Occasioned by the Convention of (intra)

Thus his eyes and ears were ever open, not, as formerly, however, with only the mere appetite for sight or sound. By consclously relaxing his will and thereby increasing 
his power to recelve impressions, he watched or listened until the "Tisdom and Spirit of the universe", Nature's own tranquil soul, seemed to steal impereeptibly into his being to commune with and refresh his spirit. He felt as we11 as saw how beautiful things were.

"From Nature doth emotion come, and moods of calmness equaliy are Nature's gift;

This is her glory." (Prelude, XIII, 1)

Nor did Wordsworth Insist that Nature's educational processes were for the mind and hoart alone. He was. confident that by her precepts, Nature could mould the physical appearance, and could impart to human qualitles and features the distinguishing characteristics of her own animated personality. In Three Years She Grew in Sun and Shower, Wordsworth gives us probably the most complete statement of his theory that contact with Nature has a formative influence on the physical being. In this exquisite, somewhat mystical poem, Nature claims the child tucy for her own, and is "both law and Impulse" to her. Under her Instruction, Lucy shall reflect the grace of moving clouds and bending trees in her movenents; the aglilty of the swift-footed fawn sha 11 be hers; and all "mute insensate things" shall contribute their calm to her development.

"The stars of midnight shall be dear-

To her; and she shall lean her ear In many a secret place Where rivulets dance the $1 \mathrm{r}$ wayward round, And beauty born of murmuring sound Shall pass into her face."

(Three Years She Grew in Sun and Shower) 
In She Has a Phantom of Delight, the perfect, lovable woman was "nobly planned" by the skillful hand of Nature.

"Her ejes as stars of Twilight falr; Like Twilight's, too, her dusky hair; But all things else about her drawn From May-time and the cheerful Dawn."

(She Was a Phantom of Delight)

But if the fair and beautiful things of Nature tend to impress their characteristic qualities upon man's being, as he glves himse if over to Nature's teachings, so do her wild and desolate aspects stamp upon him their distinguishing features, if he affronts the wise mandates of the "grave Teacher, stern Preceptress". In the wild, lawless, unkempt creature, Peter Bell, we have just such a character. Nature attempted, "through every changeful year", to find a way to reach his heart. Vainly she tempted him with soft, blue sky -- but he never felt its witchery! She offered him primroses, -- and his nature refused to respond!

"A primrose by the river's brim

A yellow promrose was to him And it was nothing more." (Peter Bell)

But although Nature could not touch his heart nor move him to silent ecstasy by lovely. forms or gentle sounds, st1li one could recognize that Peter Bell and she had been together often. He, after all, was Nature's child!

"A savage wildness round him bung As of a dweller out of doors: In his whole figure and his mien A savage character was gen of mountains and of areary moors. 
There *as a hardness in his cheek,

There was a hardness in his eye,

As if the man had fixed hls face

In many a solitary place

Against the wind and open sky."

(Peter Bell)

However, after a long and difficult struggle,

Nature reclaims Peter Bell from his wickedness.

"And now is Peter taught to feel

'That man's heart is a holy thing;

And Nature; through a world of death

Breathes into him a second breath,

More searching than the breath of spring."

(Peter Bell)

In Ruth, the savage and lawless or the irregular aspects of Nature caused a similar condition in the mind of the youthful soldier. As a child, he had found the moon and sun and streams his greatest foy; but later on, the scarletgleaming flowers, the fragrant magnolias of the tropics, -even the breezes that wove their own languor into his thoughts, -- fostered low desires and dangerous impulses in him. Also

"The wind, the tempest roaring high,
The tumult of a tropic sky,
Mlght well be dangerous food
For him, a Youth to whom was given
So much of earth - so much of heaven,
And such Impetuous blood." (Ruth)

Since this "Youth of the green savannahs" dellberately sought those things which degraded his better nature, whatever "he found 1rregular in slght or sound" in the troplcal regions 
seemed to possess kindred impu bses to his own, and to justify the evil workings of his heart. Thus does Nature Imfluence not for good those who disregard her wise tutelage, and who will not give themselves unreservedily to her kindly disclpline.

If we understand these powerg that Wordsworth ascribes to Nature as an educator of $\operatorname{man}$ or a moulding influence upon him, I think we must feel that the comparisons which he draws between man's characteristic qualities and Nature's do more than fulfull the customary requirements for comparisons as mere figures of speech. With that penetrating gift of vision which he possessed, Wordsworth seemed to discern the actual kinship between Man and Nature, which swept away the old Iines of demarcation between the two. When he makes a comparison, we feel that the resemblance lies deeper than a purely external likeness. For he does not recognize Man as belonging to a kingdom distinct and apart from Natupe, but as a part of Nature's own universal kingdom. Since "his men are spirits of the earth, wrought upon by the elements from which they are compounded", (Walter Raleigh, Wordsworth, p. 187), we appreclate more fully than before the depth of meaning his chance comparisons cover. The happy freedom of a child bespeaks a similar quality to be found in Nature.

"No fountain from its rocky cave E'er tripped with foot so feee; She seemed as happy as a wave That dances on the sea." (The Two April Mornings) The little six jear old child possesses the same delicate, 
perishable quality that characterizes a arop of morning dew.

"Thou art a dew-drop, which the morn brings forth, IIl fitted to sustain unkind ly shocks, or to be tralled along the solling earth."

(To H.G., Six Years 0ld)

As light and unexpected as: whiffs of wind that just touch and ever so slightly sway the fleld flowers on a meadow are the playful saliles of another blithe little glrl of three years .

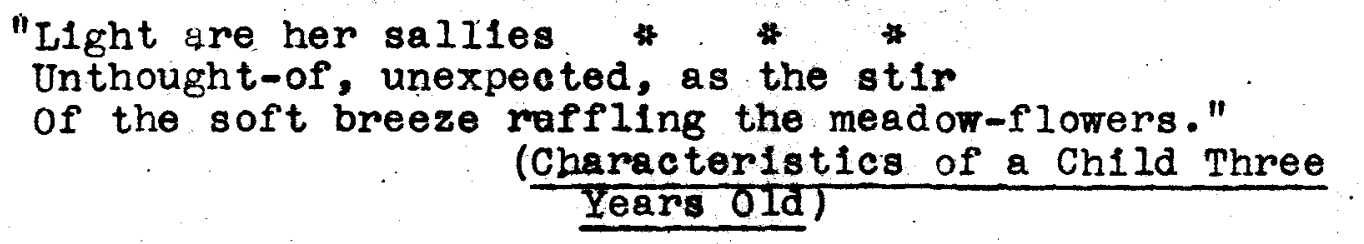

Again, Wordsworth points out the shy, retiring nature of the poet, which withdraws into itself as unobtrusiveIy as the dew disappears in the heat of the noon-day.

"He is retired as noontide dew or fountain in a noon-day."

(Poet's Epitaph)

- This same poet speaks, and the tinkling, sparkling melody of flowing streams sounds in his words.

"He murmurs near the running brooks A music sweeter than their own."

(Poet's.Epitaph)

of the beautiful Highland Girl, Fordsworth exclaims,

"Thou art to me but as a rave

of the wild sea." (To a Highland Girl)

Upon her he has no more claim than upon a wave itself which comes and goes at will on the ocean.

The loneliness of a cloud, renotely drifting this way or that without purpose over the miles and miles of sky, 
is comparable to Wordsworth feeling, as whout end in view or companion, he says,

"I wandered lonely as a cloud That floats on high o'er vales and hills."

(I Wandered Lonely as a Cloud)

In the Nature of Charles tamb, Wordsworth found "affections, warm as sunshine, free as a1r." (Written After Death of Charles Eamb). He percelves the counterparts of Lamb's humor and wit in the elements as they frollc harmlessIy about the mountain tops.

"And as round mountaln-tops the lightning plays, Thus innocently sported, braaking forth As from a cloud of some grave sympathy, Humor and wild instinctive wit, and all The vivid flashes of his spoken words."

$\frac{\text { (Written After the Death of }}{\text { Charles Lamb) }}$

From the inaccessible heights of star above us, we gain a conception of how infinitely far removed from the selfishness and worldliness of the England of Wordsworth's day was the lofty spirit of Milton. We hear, also, the kindred sound of his volce to the volce of the sea.

"Thy soul was l1ke a star, and dwelt apart: Thou hadst a volce whose sound was like the sea." (Lond on, 1802)

The illustrations seem sufficient to prove that, to Wordsworth, Nature's characteristic qualities are reproduced in the qualities displayed by man, "the child who is bone of her bone, and who inherits her form and favor." (Walter Paleigh, Wordsworth, p.189)

And this form of Nature's! With what wonderful 
Insight has Wordsworth conceived 1t, and presented it to us so that we are at all times aware of the living personality of Nature, and always distinctiy consclous that Wordsworth does not mean a human character with human shape and features. Indeed, in addressing the Brook, he says emphat1cally:

" I would not do
Like Grecian Artists, give thee human cheeks,
Channels. for tears, no Nalad should'st thou be,-
Have neither limbs, feet, features, joints nor
hairs."
(Brook! Whose Society the Poet Seeks)

Throughout his works, Wordsworth is consistent in regarding Nature as the Mother of Man and as his "prime teacher". In Yarrow Revisited, he speaks of "parent Nature", and in Expostulation and Reply, we hear Matthew say:

"You look round on your Mother Earth, As if she to no purpose bore you."

(Expostulation and Reply)

Therefore it is fitting that Nature, everywhere in his poems, should disclose those same characterist1c qualities whieh a human mother displays toward her child; and with that inherent feeling of the unity between Man and Nature, Wordsworth endows our universal parent with form and features which in the deepest imaginative sense correspond to those of a human mother.

Because the relation of a mother to her child is the tenderest, the most encompassing - in love - of all human relationships: Wordsworth ascribes to Nature those 
particular qualities and kindly attitudes which we look for in a mother. With gentle, brooding love, she watches over her children, and when all is not well with them,

"Gentle Nature grieved." (Excursion, V, 975)

It is with the truest motherly instinct that when her child

is hurt,

"Doubly pitying Nature loves to show'r

Soft on his wounded heart her healing pow'r."

(Descriptive Sketches--Quarto 1793--Reprinted,

She is "seif-respecting" Wordsworth tells us in the sixth

book of the Excursion, and because she has been the wise mother of countless generations of men, she is "venerable". With tender compassion,.

"Kind Nature keeps a heavenly door Wide open for the scattered Poor." (Devotiona I Incitements)

But more than merely to show pity, Wordsworth urges humanity to love "as Nature loves, the lonely Poor." (Highland Hut)

- No human parent is more kindly indulgent than she; she gives freely of her gifts to men.

"How bountiful is Nature! he shall find Who seeks not; and to him who hath not asked, Large measures shall be dealt."

(Excursion, IV, 466)

Yet the kindest mother must, at times, be stern. So, when her child is willful or disobedient, Náture quickly brings her displeasure to bear upon him for his own good; and when the occasion demands, she displays righteous indignation. 
"But human vices have provok'd the rod

of angry Nature to avenge her God."

(Desariptive Sketches--Quarto 1793--

Nature possesses a great, living frame, for in the poem, September,1819, the poet tells us,

"For that from turbulence and heat

Proceeds, from some uneasy seat

In Nature's struggling frame,

Some region of impatient life."

(September, 1819)

The countenance of Nature Wordsworth mentions again and again, but always with the feeling that it is the embodiment of all expressive, speaking aspects of Nature,- never with the 1da that it is a human face.

n * * My mind hath looked Upon the speaking face of earth and heaven As her prime teacher." (Prelude, V, 13)

* * $*$ The earth And common face of Nature spake to me Rememberable things." (Prelude, I, 587)

The poet tells us that he is

" * * pleased to see

In Nature's face the expression of repose."

(To the Lady. E.B. and the Hon. Miss P.)

Another time, the very austerity of her expression steengthens him:

"Stern was the face of Nature: we rejolced

In that stern countenance, for our souls thence drew

A feeling of their strength." (Recluse, I, 163)

We know that material eyes do not form a part of Nature's features, but Wordsworth makes her personality more real and more easily grasped than otherwise, by the conception of those features which he gives us. Certainly we can better visualize 
her countenance to ourselves when he tells us:

"As in the eye of Nature he has 1tred,

So in the eye of Nature let him die!

(Old Cumberland Beggar)

And as we understand the power of the human eye to change expression with varying moods, so do we appreclate the fact that Nature's eyes also manifest thet same power.

" * * Nature humbly jolns the rite, While flash her upwar eyes severe delight."

(Descriptive Sketches)

In To a Painter, Wordsworth, wishing that the artist could share with him "that inward eye" says:

"Then, and then only, Painter! could thy Art The visual powers of $\mathrm{N}_{\text {ature }}$ satisfy, Which hold, whate'er to common sight appears, Their sovereign empire in a falthful heart." (To a Painter)

Nature speaks to man, her child, in a volce most often persuasive and soothing, but at other times commanding or threatening. In the sixth book of the Prelude, Wordsworth - mentions the tones of her volce:

"Where tones of Nature smoothed by lexirned Art, May flow ir. lasting current."

(Pre lude, VI, 674).

Again, he says:

"Dread Power! whom peace and calmness serve No less than Nature's threatening volce."

(An Evening of Splendor)

Nor is her language one in which difficult rules must be mastered before Man can understand it. It is a universal language for all who care to read. The noblest aristocrat has no advantage over the poorest, most ignorant peasant in 
this respect.

"* * And the strain of thought

Accords with Nature's language - - the soft volce

of yon white torrent falling down the rocks

Speaks, less distinctiy, to the same effedt."

(Excursion, VI, 523)

Our Mother Nature has the power to smlle, whlch brings her immeasurably closer to us.

"All Nature smlies and owns beneath her eyes

Her flelds peculiar, and peculiar skies."

(Descriptive Sketches)

Her hands perform, with untiring devotion, the mission of comforting that falls to the maternal lot.

" * * The gentler work begun

By Nature, softening and concealing,

And busy with a hand of healing."

(The White Noe of Rylstone)

And those same hands, which soothe and heal, also accomplish more difflcult tasks, for

"The stars are mansions built by Nature's hand, And, haply, there the spirits of the blest Dwell, clothed in radidnce, the ir imnortal vest." (The Stars are Mansions Built by ratare's Hand)

The power to breathe animates her mighty being. Wordsworth; in describing Peele castle which stood in a tranquil spot by the sea, observed that nether sound nor motion disturbed the perfect quiet of place save

$" \quad \therefore$ * the moving tide, a breeze, or merely silent Nature's breathing life."

(Elegiac Stanzas, suggested by pleture of peele Castle)

In another happy'hour, he says: 
* Universal Nature breathed As with the breath of one sweet flower."

(Seque 1 to the 'Beggars')

Again the poet's heart is filled with unutterable peace at "* * the calm That Nature breathes among the hills and groves." (Prelude, I, 280)

But it is the soul of Nature, that "soul of beauty and enduring Life", which surrounds man's soul with its "ennobling harmony" and lifts 1t to exalted helghts above the "self-destroying, transitory things" of life. It is that which links man's spirit to "the Soul of all the Worlds", and through which humanity recovers from its feverish restlessness, its unquenchable thirst for power and wedith, and blends itself with Nature.

"O Soul of Nature! excellent and falr! That didst rejolce with me, w1th whom $I$, too, Rejolced through early youth."

(Prelude, XII, 93)

"From Nature and her overflowing soul, I had recilved so much, that all my thoughts Were steeped in feeling." (Prelude, II, 397)

"Wisdom and Spirit of the Universe! Thou Soul, that art the Eternity of thought! And giv'st to forms and Images a breath And everlasting motion, not in vain, By day or star-light, thus from my first dawn of childhood didst thou intertwine for me The passions that bulld up our human soul." (Influence of Natural Objects)

Thus, with her soul enveloping and enriching his own, Nature began the work of bringing Wordsworth to recognize man as "Earth's paramount creature",

"As long as he shall be the child of earth." (Prelude, V, 25) 



\section{The "Open Schools" -- Humanity.}

When Wordsworth sought Nature's soothing power to heal his troubled heart and perplexed mind, the poet tells us that gradually he became aware of a change in his feeling toward Nature.

"** Nature, destined to rema in wo long Foremost in my affections, had fallen back Into a second place, pleased to become A handmaid to a nobler than herself."

(Prelude, XIV, 256)

His predominant interest now became Man, and in order to understand humanity a a whole, Wordsworth first directed his attention to the study of the individual and the human mina. For he realized that by Nature's unceasing training he was now fitted to undertake the task.

"Long time in search of knowledge did I range The field of human life, in heart and mind Benighted; but the dawn beginning now To reeappear, 'twas proved that not in vain I had been taught to reverence a Power That is the visible quality and shape And Image of $r 1$ ght reason; that matures Her processes by steadfast laws; gives birth To no impatient or fallacious hopes, No heat of passion or excessive zeal, * * * * * but trains

To meekness, and exalts by humble faith;

Holds up before the mind intoxicate

With present objects, and the busy dance

of things that pass may, a temperate show

of objects that endure." (Prelude, XIII, 16)

And thus we find Fordsworth, at this time, seeking 
"In man, and in the frame of soclal life, Whate'er there is desirable and good of kindred permanence." (Prelude, XIII, 35)

Through the countless, varied, ducational precesses which Nature employed to teach wordsworth the unity existing between herself and man, the poet at last was able to comprehend how Man's mind has the power to become more wonderful than the earth on which he 11ves. As Tordsworth gradually adjusted himself to calmness and reflection, Reas on asserted Itself, and "clearest Insight, amplitude of mind" resulted from these conditions. Therefore, it followed naturally that

- "Thus moderated, thus composed, I found Once more in Man an object of delight, of pure Imagination, and of Love."

(Pre lude, XIII, 48)

With convictions more sure than ever before, he renewed his trust in Man's essential spiritual dignity and moral worth, recognizing him as

"All-beholding Man, Earth's thoughtful lord." (Excursion, VIII, 164)

Ambitious'schemes and ppojects for the betterment of mankind no longer, as in his early manhood, occupled his mind. In these later years, he saw all things in their true proportion, undistarbed by fancy, and he was content to seek the good in the here and now, bullding on that his hopes for future happiness.

"F * I sought
For present good in $11 \mathrm{fe}^{*}$ s familiar face,
And built thereon my hopes of good to come." (Prelude, XIII, 6I) 
Because Wordsworth felt that "the great city". lacked many of the things which vould enable him to get nearer to other men, he tells us that

" * * Therefore did 1 turn To you, ye pathways, and lonely roads, Sought you enriched with evergthing I prized, With human kindnesses and simple joys. (Prelude, XIII, 116)

Accordingly, Wordsworth wandered along the highways, studing with lowing inquisitiveness the people as they passec "on the windings of the public way." Here in these "open schools", he learned that a poet is truly "a man speaking to men". On these roads he found that

$$
\begin{aligned}
& \text { "We also meet a friend." (Prelude, XIII, 138) } \\
& \text { (Pro meet a face, }
\end{aligned}
$$

He not only studied those whom he met, but he stopped to talk with them; in these conversations, he endeavored to glean from the "fluxes and refluxes" of their minds when aroused by the "great and simple affectlous" insight into the depth of their souls, that to the careless observer seemed to have no depth at all.

"* * When I began to enquire, To watch and question those I met, and speak Without reserve to them, the lonely roads Were open schools in which I daily read With most delight the passions of mankind, Whether by words, looks, s1ghs, or tears revealed; There saw into the dopth of human souls, Souls that appear to have no depth at all To careless eyes." (Prelude, XIII, 160) 
unheeded by the poet. In the most ancient, decrepit beggar, he found qualities that made human nature a sacred thing, worthy of his consideration and reverence. Each person whom he met was, to Tordsworth, a new and fascinating experience, and from these experfences he learned lessons which he presents to us as his wisest teachings.

The Leech-gatherer, old and poorest of the poor, yet had that message to give Nordsworth, which moved him profoundly, and proved a highest inspiration to him. One beautiful, invigorating morning, with one of those sudden, unaccountable changes that often come over us, Nordsworth was reduced from a state of utter happiness, such as he had experienced as a boy, to the lowest depths of defection.

"And fears and fancles thick upon me came, Dim sadness -- and blind thoughts, I knew not, nor could name." (Resolution and Independence.)

Although he felt as much "a happy child of earth" as the singing skylark or the playful hare, a strange fopeboding crept over him that

"There may come another day to me --

Solitude, pain of heart, distress, and poverty."

(Resolution and Independence)

He was haunted by the wretched remembrance that

"Te Poets in our Youth begin in gladness, But thereof come in the end despondency and madness." (Resolution and Independence)

Wordsworth knew this fact to be only too true in the case of 
the majority of poets; and while struggling with these "untoward thoughts", he saw an old, old man, his body noticeably bent and twisted, standing propped age inst his long, gray staff and gazing fixediy in to the muddy pond.

The sight of this stranger promised now adventure In the fleld of human nature, and Wordsworth, always eager as a boy in search of it, engaged the old Ieech-gatherer in conversation. Sk1lifully directing his questions so that he could lead the ancient man to speak of himself and his occupation, Fordsworth was astonished to find his speech stately, as well as courteous.

"With something of a lofty utterance drest -Choice word and measured phrase, above the reach of ordinary man." (Resolution and Independence)

The old man related how from pond to pond he wandered over the lonely moor in search of leeches, and how exhausting was his task. Yet, instead of complaining of his hard lot, he expressed pride and thankfulness that, by this labor and with God's help, he could live honestly. Almost unable to persuade himself that he was not dreaming, Nordsworth listened, and as his own troubled thoughts returned, he begged the Leechgatherer to repeat his words, by asking him again:

"How is it that you live, and what is it you do?" (Resolution and Independence)

Kindly, the aged man explained a second time how he managed to Ilve, and, apparently undismayed by the fact 


\section{8.}

that leeches were fast disappearing, he added:

"Yet st1ll I persevere, and find them whore I may."

(Resolution and Independence)

In such philosophy, Nordsworth found the help he needed to Ift the distress from his own heart. He was both ashamed and glad to discover such oheerful courage and determination In 'so infirm an old man; and with scorn, now, for his fears, he cried:

"'God', said I, 'be my help and stay secure; I'II think of the Leech-gatherer on the lonely moor!'" - (Resolution and Independence)

Although the unobserving, thoughtless person passed them by unnoticed, these qualities which make the human character strong could not be hidden by age or poverty; Wordsworth was fast learning that "man was dear to man", and no matter how humble, how decrepit a human creature might be, he was worthy of understanding sympthy and genuine respect.

In the old Cumberland Béggar, apparently a "burthen of earth", Wordsworth also found a character who unconsclously influenced all with whom he came in contact. The poet remembered that, as a child, he had seen the por old man begging from door to door, and now, scarcely able to wander about day afer day, the anclent creature seemed to be of no use in the world, whatever. Yet to Wordsworth, intent on his study of man, was revealed the fact that this Beggar played a definite and very necessary part on earth. 
His feebleness moved the "sauntering Horseman" to stop and place his alms carefully in the old man's hat, instead of thoughtlessiy flinging them upon the ground as he rode by. The woman who kept the toll-gate intermupted her work to lift the latch for the aged man; the post-boy, the villagers, both young and old, performed little kindly deeds, "acts of love" and pity, for the poor old mendicant. For this great service which he rendered to mankind, Wordsworth blessed his bowed and aged head.

" * * The villagers in him Behold a record which together binds Past deeds and offices of charity Else unremembered, and so keeps a live The kindly mood in hearts which lapse of years, And that half-wisdom, half-experience gives, Make slow. to feel, and by sure steps reslgn To selfishness and cold oblivious cares." (old Cumberland Beggar)

$* \quad * \quad * \quad *$

"Then let him pass, a blessing on his head! And while in that vast solitude to which The tide of things has borne him, he appears To breathe and live but for himself alone, Unblamed, uninjured, let him bear about The good which the benignant law of Heaven Has hung around him; and while life is his Still let him prompt the unlettered villagers To tender offices and pensive thoughts." (0la Cumberland Beggar)

As recompense, Wordsworth desired that the freedom of Nature should be the old Beggar's while he lived -- the freshness of the vilieys, the sweep of the wind, the silence of mountains, the music of birds, and the light and warmth of the sun. 
Thus we find that Fordeworth, through his deferential interest and veneration for individuals such as the Leech-gatherer and the old Cumberland Beggar, arrived at that sympathetic comprehension $6 f$ the affections, joys, and griefs of humanity which established in him a reverent understanding of the inherent grandeur of all human $11 \mathrm{fe}$. The men, women, and children that he describes In his poems display those "essential passions of the heart" that are common to all men, and are, therefore, natural feellngs: Their lives reflect the human virtues, faults, and emotions to be found in the lives of men, and consequently Wordsworth really keeps the reader "In the company of flesh and blood".

Thu's, the instinct of mother-love, whether it be manifested in an Indian mother or in a poor, mad, deserted woman, is a palpable emotion which Wordsworth does not attempt to explain in elaborate phraseology, but which he a accepts as unquestionably natural. Therefore, he presents It to us in simple, natural language. In Her Eyes are M11a, her chlld has given the mother something for which to live, when the very foundations of her reason are gone.

"Sweet babe! they say that I am mad,

But nay, heart is far too glad;

To thee I know too much I owe;

I cannot work thee any woe.

For I thy own dear mother am."

(Her Eyes are Wild) 
And in the line,"For thee bold as a lion I will be," the Innate impulse of the mother-heart to protect 1 ts young is only one of the "essential passions" expressed in the most unaffected way.

The unhappy mother in the Thorn, deprived of her child, and therefore of any incentive to strive for happiness, presents the other side of the story -- desertion without compensation. In the desolate misery of Martha Ray, we have a stralghtforward portrayal of human misfortunes, trivial though they may be to the world at large, Martha's wretchedness instructs us how much of passion and of pain may lie in suffering that is ordinary in the sense of not being extraordinary. This is the poet thinking and feeling in the spirit of the passions of mankind. It is the poet writing, not for poets alone, but for men.

The relationship between father and child also came under Wordsworth's observation in his study of man. The Two April Mornings deals with the tragedy in the Ife of Matthew, the old schoolmaster. As Fordsworth and Matthew walked together on one exquisite April morning, when the very charm and colorful beauty of the surroundings should have been conducive to joyousness, the poet was astonished to hear Matthew slgh. He a aked in surprise:

"* What thought
Beneath so beautiful a sun
So sad a sigh has brought?".

(The Two April Mornings) 


\section{2.}

And the schoolmaster told him of another April morning, "of this the very brother", though "full thirty years behind". On that morning, he had stood beside his daughter's grave --

"Nine summers had she scarcely seen, The pride of all the Vale; And then she sang: - she would have been A very nightingele." (The Two April Mornings)

This is the human touch that makes Hatthew akin to all fathers,- his pride in the little firl who would, not might, have been a mightingale, he knev.

The Fountain relates another conversation between Wordsworth and Matthew, in which the poet offers to f1Il the empty place in the old man's heart.

"'And, Matthew, for thy children dead I'II be a son to thee!' At this he grasped my hand and sald, 'Alas! that cannot be.'" (The Fountain)

Such, from his study of human nature, did Wordsworth percelve tha natural relation between a father and his child to be, that no outsider could possibly enter into it, much as he might desire to do so.

Everywhere in his poems dealing with human nature, Wordsworth emphasizes the qualities of endurance and fortitude which enable man to go on performing the routine tasks of daily life, even though sorrow has come to hIm. old Timothy, in The Childless Father, is an illustration of 
this fact; and after the funeral of his last child, his quiet resignation as he takes up his staff to go to the chase, is but "prosalism"of life. Most of us know Just such a Timothy as this one who

"Perhaps to himself at that moment said, 'The key I must take, for my Ellen is dead." But of this in my ear not a word did he peak, And he went to the chase with teap on his cheek." (The Childless Father)

In Michael, Wordsworth portrays a perfect range of domestic affections. Suroly this poem speaks the "language of men" and deals with the simple, familiar incidents of life. Here, "the elementary feelings are less under restraint, and speak a more emphatic language", Indeed. (Lyrical Ballads, Preface, p. 226). For in the Introduction Wordsworth himse if says:

" * haring felt the power
of Nature, by the gentle agency
of natural objects, led me on to feel
For passions that were not my own, and think
(At random and Imperfectly indeed)
On man, the heart of man, and human life."
(Michael)

The exceedingly strong and tender love with which Michael surrounded Luke, - a love even greater than his deep affection for his old wife, because of the hopes he cherlshed for his son's future,- his honest pride in his land,that eternal love of possessions in man -- all these are but feelings exhibited by mankind everywhere today. Though weighed down by the sorrow of his son's disgrace, the dignity and fine 
courage of the old peasant mist be "felt in the blood and felt along the heart "of each one of us.

And in the midst of grief, Michael realizod the potency of love to help him:

"There is a comfort in the strength of love,

'Twill make a thing endurable which else

Would overset the brain, or break the heart." (Michae I)

Ne1ther protesting against the heart-breaking circumstances that caused the sorrow and anguish in Michael's Iife, nor attempting to smooth over the genuine tragedy of the story in any may, Wordsworth tells the simple narrative very simply. Matthew, after a time, took up the work on the sheepfold again,

" * * and as before, Performed a 11 kinds of labor for his sheep, And for the land, his sma 11 inheritance."

(Michae 1)

But before It was finished; the old man died; and years afterwards, when great changes took place in the neighborhood, only the great old oak tree that stood near Michael's cottage, tho "boisterous brook", and the unfinished sheepfold remained. Among other "elementary feelings", fraternal.

attachment is one that always has existed and always will be manifested as long as that relationship endures among men. Wordsworth seems to reach the depth of brotherly affection, to comprehend the motives and feelings of the mariner in 
The Brothers perfectly. Leonard and James had been "pais" from boyhood, and were almost Inseparable. When, the brothers were left destitute, Leonard went to sea to seek hls fortune for his brother's sake, and when after many years he was able to return, he found strange faces in the v1llage, and strange graves in the churchyard. Unrecognized, he questions the village priest cautiously and timidly, fust as persons do when they suspect some disastrous happening and crave, yet dread, to know the truth. The priest told this apparent stranger about the death of the brother James who was left at home after Leonard, the other boy, had set out to sea.

"The stranger would have thanked him,- but he felt A gushing from his heart, that took away The power of speech, Both left the spot in silence; And Leonard, when they reached the churchyard gate, As the Priest If ted up the latch, turned round,And, looking at the grave, he said, 'My Brother!' The Vicar did not hear, the words; and now He pointed toward his dwelling place,entreating Thet Leonard would partake his homely fare; The other thanked him with an earnest volce; But added, that, the evening being calm, He would pursue his journey."

(The Brothers)

I felt particularly in reading this poem, that "the feeling therein developed gives importance to the action and situation, and not the action and situation to the feeling." (Lyrical Ballads, Preface, p. 230).

In his ardent study of human nature, Wordsworth did not overlook chlldren. They also have human thoughts, 
ways, and characteristics which fascinated the poet; and although not always thoroughly at ease with chlldren, Wordsworth delighted to watch them and talk to them. Eager to learn from them, he questioned them endessly, and gratefully acknowledged the illumination the ir artless peplles brought to him.

In the Ode on Intimations of Immortality, Wordsworth expresses the belief that the child sees more clearly than the man-- can read more tmuly "the eternal deep". But this "visionary gleam" fades as the child grows older, and in maturity it is entirely lost.

"But trailing clouds of glory do we come From God, who is our home;

Heaven lies about us in our infancy!

Shades of the prison house begin to close Upon the growing Boy,

But he beholds the light, and whence it flows,

He sees it in his joy.

At length the Man percelves it die away

And fade into the light of common day."

(Ode on Intimations of Immortality)

In We Are Seven, Wordsworth relates his conversation with a little girl which conflemed and streng thened the belief set forth in the ode. On questioning the little mald about her brothers and sisters, Wordsworth learned that she had seven,-

"'And two of us at Conway dwell,

And two are gone to sea.

'Two of us in the churchyard be, My sister and my brother; And in the churchyard cottage, I Dwe 11 near them with my wother." (We Are Seven) 
With stupid insistence, Wordsworth argued with the child that if two of them were dead, they were no longer able to ran about with her, and consequently there could only be five brothers and sisters left. In vain he tried to move the child to reason as he did. With matter-of-fact certainty, she persisted in her first statement.

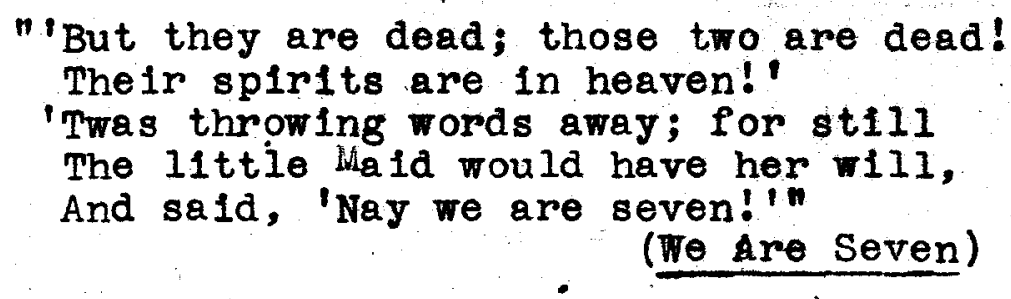

To the little girl, the mystery of death had brought no change In the number of her brothers and sisters, and therefore it presented no difficulty to her mind as it did to Wordsworth's adult intelligence. She was not stubborn in her refusal to admit that there were only flve of then left. And the Importance of this inc1dent ot Wordsworth lay in the fact that it was perfectly obvious to her that they really were seven in number. To the poet, this assurance seemed to come from something within the child, which he, because of his maturity, did not possess. He saw her as a child

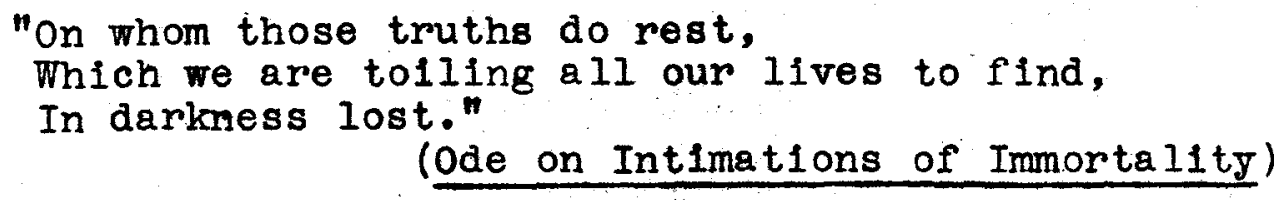

Another experiment that brought interesting results to Hordsworth was his conversation with a little boy, 
five years old, the son of his friend. As the poet and the child strolled about the grounds of his home, Wordsworth idly asked the child,

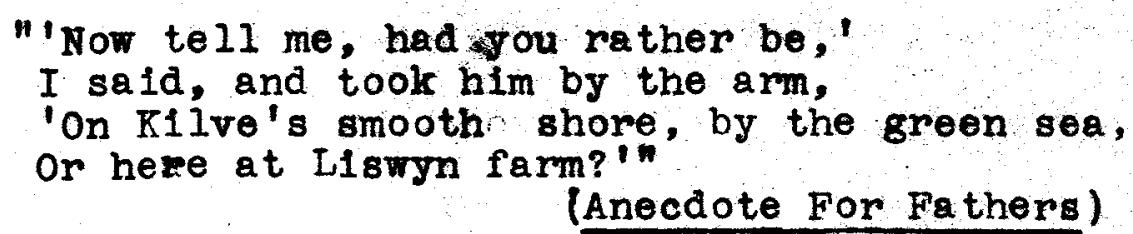

The child, with equal carelessness, answered:

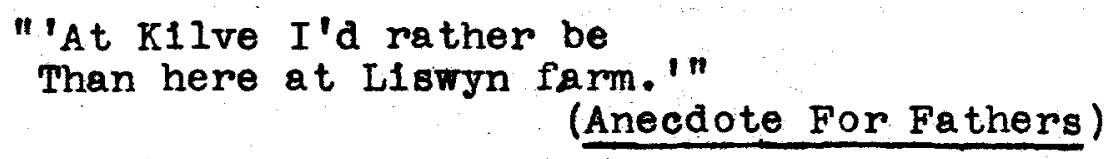

To the little boy this was answer sufficlent to close the matter, but Wordsworth, eager to explore further the enild's reasons for such a reply, asked him why he preferred to be at Kilve rather than at the farm. The boy, having no reason ao all for his preference, frankly sald,

\section{"I cannot tell, I do not know." (Anecdote For Fathers)}

Nevertheless, the poet was determined to find out, and three times he repeated his question, whlle little Eduard hung his head, embarrassed and unhappy. Then as he looked up suddenly, his eyes rested on a bright, glided weathemrane on the roof of the house. Totally at a loss before for something to give as his reason, the child Immediately grasped at the weathercock as a tangible excuse, and now he readily of fered to 
Wordsworth.

"At K1lve there was no weather-cock, And that's the reason why.' in

The lesson was obvious enough to Wordsworth, and he mumbly and thankfully took $1 \mathrm{t}$ to heart.

"O dearest, dearest boy! my heart For better lore rould seldom yearn, Could I but teach the hundredth part of what from thee I learn."

(Anecdote foo Fathers)

Wordsworth's position as a poet is not to be determined by the literary herit of these poems He did not write them, nor do we read them for any beanty of expression or of style. But they show how the poet proceeded in his quest for knowledge and understanding of the human mind; they show how, absolutely without any system or means other than his observations of Nature and his fellow-men, and his own habits of introspection and reflection, he became a psychologist and a phflosophical teacher.

Certalnly no one will question the difference between the language of We Are Seven and the Ode, for Instanee, or the sonnet, It is a Beauteous Evening, Calm and Free. But the very simplicity of poems 11ke We Are Seven, or Anecdote for Fathers, has something noble in 1 t; and a truly sincere style can, as the subject demands, be elther childilike or magnificient, just as a really noble nature may be clothea 
in the garments of peasant or of an aristocrat. These poems which relate his experimental observation and questioning of living people are but laboratory exercises in which we are permitted to wateh Wordsworth work. In the poem, It is a Beauteous Evening, Caim and Free, we have the essence of all that the poet discovered in his experiments with children In 1 ts finished state, - a marvelously perfect expression, which is the consummation of the poets observations combined With exquisite poetic diction and form.

"Listen! the mighty Being is awake, And doth with his eternal motion make A sound like thunder - everlastingly. Dear Child! dear Girl! that walkest with me here, If thou appear untouched by solemn thought, Thy nature is not therefore less divine: Thou liest in Abraham's bosom all the year; And - worsip'st at the Temple's inner shrine, God being with thee when we know it not."

(It is a Beauteous Evening, $\mathrm{CaIm}$ and rree)

From his study of the chlldren, men, and women. who lived around him in the vale or passed him on the highway, Wordsworth has pictured the trials, the emotions, the thoughts, and the characters that are common to us all. Mankind reflects the same feelings and actions today; qualitles of endurance, perseverance, Independence, courage, and kindness, and the ir opposites exist now as then; and love is still an eternal instinct. And so I repeat that Wordsworth did not write his poetry for another poet or for some sage philosopher, but for those who "think and feel". Brlefly, then, we learn how 


\section{1.}

Wordsworth, having been awakened to reverent love for humanity through his devout love of Nature, was led by her to see that, in his pooper environment of Nature, Man takes his rightiul place.

"Outwardly, inwaraly contemplated, As, of ali isible natures, crown, though born of dust, and kindred to the worm; a Being, Both in perception and discernment, first In every capability of rapture, Through the divine effect of power and love; As, more than anything we know, instinct With godhead, and, by reason and by will, Acknowledging dependency sublime."

(Frelude, VIII, 485) 
CONCLUS ION. 
Conclusion.

First with Nature and later with Man as his teachers, during those years that brought the "ph1losophica mind", Wordsworth reached

" * truths that wake, To perish never." (Ode on Intimations of Immortailty).

He found principles of happiness and joy animating all Nature, which Man, as a part of Hature,- her Child, indeed,may share.

"And 'tis my falth that every flower Enjoys the air it breathes. * * * * The budding twigs spread out the ir fan; To catch the breegy air; And \pm must think, do al1 I can, That there 18 pleasure there."

(Lines written In Early Spring)

And he attained at last,

" * * to confident repose

In God; and reverence for the dust of Man." (Excursion, VII, 1057)

With a positive and serene faith, which a knowledge of human suffering and hardship could not shake, he recognized that the controliing law of the universe is love -- that it is a God-made law, and therefore, divine. 
"Love, now a universal bitth,

From heart bo heart is stealing,

From earth bo man, from man to earth;

-- It is the hour of feoling."

And from the blossed power that rolis

About, below, above,

Willeframe the measure of our souls;

They shall be turned to love."

(To My Sister)

It is this law of love that joins, In one great, continuous chain, the infinitely great with the smallest things in ïature,-- that holds the earth "constant to her sphere", and at the same time makes the Primrose clinging to the rock

"A lasting link in Nature's chain

From highest heaven let down:"

(The Primrose on the 'Rock)

I, for one, feel that Wordsworth determinedly

- broke away from musty, ordered systems of phllosophy and thought, to teach those things which, from his own experlence, he knew would refresh and ennoble Man's soul. And with his teachings, Wofdsworth "satisfies the heart; he inspires and ftimulates the thought". With his ever encouraging volce, "he becomes to us more than a poet -he is our guide, philosopher, and friend." (Dawson, Literary Leaders of Modern England, p. 59). Truly, we cannot offer him higher tribute than to say he comes to us 


$$
65 .
$$

"like the presence of Nature herself", with the power "to touch 'the depth and not the tumult of the soul', to glve us quietness, strength, steadfastness, and panpose, whether to do or to endure." (Morley, Introduction to Wordsworth's Poetical Works, p. 16)

"To know him is to learn courage; to walk with him is to feel the visitings of a larger, purer a $1 r$, and the peace of an unfathomable sky." (Ralelgh, Wordsworth, p. 228) 
BIBLIOGRA PEY. 
Bibllography.

Arnold, Matthew

Coverthope, W.F.

Dawson, Tllilam J.

Herford, C.H.

Hutton, R.H.

Knight, William

Morley, John

Rale1gh, Walter

Smith, N.C.

Taine, A.H.

Willa ims on, Claude

Wordsworth

Nordsworth

Wordsworth
Eesags in Critlelsm.

H1story of English Pootry, Vol, 6.

Literary Leaders of Modern Englind.

Ago of Wordsworth. (5th ed, 1903)

Essays in Ilterapy Criticlsm.

Life of Wordsworth. ( 3 vol, 1889)

Introduction to his edition of Wordsworth's Poems.

Wordsworth.

Introduction to his edition of - Wordsworth's Poems.

- World's Grea test Li tera ture.

Writers of Three Centuries.

Poems. Oxford edition, ed. by T. Hutchins on, 1895.

Poems. Ed. by Eduard Dowden.

Lyrical Ballads. Ed. by H, Llttledale, I9I1. 